\title{
Stimulation of iodide uptake by human chorionic gonadotropin in FRTL-5 cells: effects on sodium/iodide symporter gene and protein expression
}

\author{
Franco Arturi, Ivan Presta, Daniela Scarpelli, Jean-Michel Bidart ${ }^{3}$, Martin Schlumberger ${ }^{3}$, Sebastiano Filetti ${ }^{2}$ \\ and Diego Russo ${ }^{1}$ \\ Dipartimento di Medicina Sperimentale e Clinica and ${ }^{1}$ Dipartimento di Scienze Farmacobiologiche, Università di Catanzaro 'Magna Graecia', \\ 88100 Catanzaro, Italy, ${ }^{2}$ Dipartimento di Scienze Cliniche, Università 'La Sapienza', Rome, Italy and ${ }^{3}$ Institut Gustave Roussy, Villejuif, France \\ (Correspondence should be addressed to S Filetti, Dipartimento Scienze Cliniche, Clinica Medica 2, Policlinico Umberto I, Viale del Policlinico, \\ 155-00161 Rome, Italy; Email: sebastiano.filetti@uniroma1.it)
}

\begin{abstract}
Background: Various clinical and experimental findings support the concept that human chorionic gonadotropin (hCG) can stimulate iodide uptake in thyroid cells.

Design: We investigated the molecular mechanisms underlying the effects of hCG on iodide uptake, and particularly its action on the expression of $\mathrm{Na}^{+} / \mathrm{I}^{-}$symporter (NIS) mRNA and protein.

Methods: Iodide uptake was analyzed in FTRL-5 cells by measuring ${ }^{125} \mathrm{I}$ concentrations in cells after a 30-min exposure to $0.1 \mu \mathrm{Ci}$ carrier-free $\mathrm{Na}{ }^{125} \mathrm{I}$ in the presence or absence of hCG or, for control purposes, TSH. Expression of NIS mRNA and NIS protein synthesis were evaluated, respectively, with a semiquantitative 'multiplex' RT-PCR method and Western blot analysis.

Results: Iodide uptake was increased by hCG in a dose- and time-dependent manner: maximal effects were observed after $72 \mathrm{~h}$ of stimulation. The effect was cAMP dependent and paralleled that of TSH, although it lacked the early cycloheximide-independent component seen with TSH, and its peak effect was lower. Semiquantitative multiplex RT-PCR revealed that hCG produced a significant increase in NIS mRNA levels that was detectable after $4 \mathrm{~h}$ and peaked after $48 \mathrm{~h}$. In contrast, in TSH-stimulated FRTL-5 cells, maximum NIS mRNA expression was observed after $24 \mathrm{~h}$ of stimulation. Western blot analysis demonstrated that hCG also caused a 2.5-fold increase over basal values in NIS protein levels, which was similar to that observed after TSH stimulation although the peak effects of the latter hormone were less marked and occurred earlier.

Conclusion: Our data demonstrated that hCG stimulates iodide uptake in FRTL- 5 cells by increasing NIS mRNA and protein levels. Thus, the functional status of the thyroid may be influenced by hCG-dependent changes in NIS expression occurring during pregnancy.
\end{abstract}

European Journal of Endocrinology 147 655-661

\section{Introduction}

A number of clinical and experimental findings support the concept that human chorionic gonadotropin (hCG) is a thyroid stimulator $(1,2)$. The thyrotropic action of this hormone has been attributed to its direct interaction with the thyrotropin (TSH) receptor $(3,4)$. Several in vitro studies have demonstrated that hCG can increase iodide uptake and cAMP production and induce growth in rat FRTL-5 cells $(5-7)$. Hershman et al. (5) showed that highly purified hCG and partially purified commercial preparations of this hormone display similar potencies in increasing iodide uptake and activating adenylate cyclase. This observation suggests that the thyrotropic effects of hCG are produced by the hormone itself, rather than by its molecular variants, i.e. free subunits and fragments present in impure preparations (5). Similarly, human thyrocytes cultured in collagen have been found to respond to hCG by increasing iodide uptake, cAMP synthesis and iodide organification (8).

The sodium/iodide symporter (NIS) protein is responsible for the transport of iodide from the basal to the apical membrane of the thyrocyte (9). Attempts have been made to identify the molecular mechanisms of iodide transport in thyroid cells and its regulation by TSH and other agents under both normal and pathologic conditions (10-12). Thus far, however, the mechanism underlying the stimulatory effects of hCG on this process has not been described. Therefore, in this study, the effects of hCG and TSH on iodide transport and expression of NIS mRNA and protein were investigated 
using the well-characterized FRTL-5 cell line. We found that hCG increases the levels of the NIS protein primarily through its effects on NIS gene expression, thus explaining the enhanced iodide uptake.

\section{Materials and methods}

\section{Cell cultures}

FRTL-5 cells were grown in 12-well tissue culture dishes for the measurement of ${ }^{125} \mathrm{I}$ uptake and in $100 \mathrm{~mm}$ diameter dishes for both RNA and protein extraction. Coon's modified Ham's F-12 medium was supplemented with 5\% calf serum, penicillin/streptomycin, amphotericin $\mathrm{B}$ and a six-hormone mixture containing bovine insulin $(10 \mu \mathrm{g} / \mathrm{ml})$, hydrocortisone $\left(10^{-8} \mathrm{~mol} / \mathrm{l}\right)$, transferrin $(5 \mathrm{mg} / \mathrm{ml})$, somatostatin $(10 \mu \mathrm{g} / \mathrm{ml})$, glycil-histidyl-lysine $(10 \mathrm{ng} / \mathrm{ml})$ and bovine TSH $(1 \mathrm{mU} / \mathrm{ml})$, as previously described (13). Medium was replaced when cells reached $70-80 \%$ confluence. Prior to individual experiments, cells were maintained for 7 days in the same culture medium with all hormones except TSH.

\section{${ }^{125}$ I Uptake}

${ }^{125}$ I Uptake by FRTL- 5 cells was measured as previously described (14). Briefly, cells were split and seeded into 12-well plates and, after aspiration of the culture medium, they were washed with $1 \mathrm{ml}$ Hank's balanced salt solution (HBSS) (Life Technologies S.r.l., San Giuliano Milanese, Milan, Italy) supplemented with Hepes (10 mM, pH 7.3). ${ }^{125}$ I Uptake was initiated by adding to each well $500 \mu \mathrm{l}$ buffered HBSS containing $0.1 \mu \mathrm{Ci}$ carrier-free $\mathrm{Na}{ }^{125} \mathrm{I}$ (Amersham Pharmacia Biotech, Cologno Monzese, Milan, Italy) and $10 \mu \mathrm{M}$ NaI (Sigma-Aldrich S.r.l., Milan Italy) to obtain a specific activity of $20 \mathrm{mCi} / \mathrm{mmol}$. In half of the wells, used as controls for specific uptake, this assay buffer also contained $10 \mu \mathrm{M} \mathrm{KClO}_{4}$, which is an NIS inhibitor. After $30 \mathrm{~min}$ at $37^{\circ} \mathrm{C}$ in a humid atmosphere, the radioactive medium was aspirated, and the cells were washed with $1 \mathrm{ml}$ ice-cold HBSS. To determine the amount of ${ }^{125} \mathrm{I}$ associated with the cells, $1 \mathrm{ml} 95 \%$ ethanol was placed in each well and left for $20 \mathrm{~min}$ before being transferred into vials for counting with a gamma counter. Iodide uptake was expressed as $\mathrm{pmol} / \mu \mathrm{g}$ DNA. DNA was measured using a kit provided by Bio-Rad Laboratories S.r.l. (Segrate, Milan, Italy). Each experiment was carried out in quadruplicate at least twice, and Chinese hamster ovary cells were used as negative controls.

Iodide uptake (described below) was evaluated after stimulation with hCG and with TSH. In preliminary experiments, FRTL-5 cells were stimulated with highly purified human chorionic gonadotropin (CR129, specific activity $11300 \mathrm{IU} / \mathrm{mg}$, produced by Dr A F
Parlow and obtained through the National Hormone and Pituitary Program of the NIDDK) and with a commercial preparation of purified hCG (specific activity $14000 \mathrm{IU} / \mathrm{mg}$ ) purchased from Sigma-Aldrich S.r.l. As reported by Hershman et al. (5), there were no significant differences between the effects of these two preparations (data not shown). Therefore, in the experiments reported in this paper, the less costly commercial preparation was used for hCG stimulation. TSH, as well as ouabain, $\mathrm{KClO}_{4}$, forskolin, dibutyryladenosine $3^{\prime}-5^{\prime}$-cyclic monophosphate $\left((\mathrm{Bu})_{2}\right.$ cAMP) and cycloheximide, were obtained from Sigma-Aldrich S.r.l.

\section{RNA extraction and semiquantitative RT-PCR}

Total RNA was extracted from FRTL-5 cells using the RNA Fast Kit (Genenco; M-Medical, Florence, Italy) according to the manufacturer's instructions. cDNA was synthesized from $1 \mu \mathrm{g}$ total RNA, as previously described (15). The mixture was incubated at $25^{\circ} \mathrm{C}$ for $10 \mathrm{~min}$, at $42{ }^{\circ} \mathrm{C}$ for $60 \mathrm{~min}$, heated to $99^{\circ} \mathrm{C}$ for $5 \mathrm{~min}$, and then stored at $-20^{\circ} \mathrm{C}$. A semiquantitative multiplex RT-PCR was designed (16) to compare the RT-PCR products of the NIS gene with those of the glyceraldehyde-3-phosphate dehydrogenase (GAPDH) gene to determine their relative expression levels. PCR amplification was performed using $5 \mu \mathrm{l}$ cDNA, and the samples were subjected to 32 cycles of amplification, as follows: cycle 1: denaturation at $95^{\circ} \mathrm{C}$ (10 min); cycles $2-31$, each of which included denaturation at $95^{\circ} \mathrm{C}(30 \mathrm{~s})$, annealing at $60{ }^{\circ} \mathrm{C}(30 \mathrm{~s})$ and extension at $72^{\circ} \mathrm{C}(30 \mathrm{~s})$ for 30 cycles; cycle 32 : $72^{\circ} \mathrm{C}$ for $7 \mathrm{~min}$. Primer oligonucleotides for the rat NIS gene were: $5^{\prime}$ primer, 5'-GCTGTGGCATTGTCATGTTC$3^{\prime}$ and $3^{\prime}$ primer, 5'-ACACTGACACCTTCTGGAGT- $3^{\prime}$. The amplification yielded a 219 base pair DNA product whose sequence corresponded to that of fragment 1002-1220 of the rat NIS gene (9). Primer oligonucleotides for the rat GAPDH gene were: $5^{\prime}$ primer, 5'-TTCACCACCATGGAGAAGGCT-3' and $3^{\prime}$ primer, 5'ACAGCCTTGGCAGCACCAGT-3'. The amplification yielded a 347 base pair DNA product corresponding to fragment 1147-1493 of the rat GAPDH gene, as reported in the Gene Bank (accession no. AF 106860). To ensure that the amplification of both rat NIS and rat GAPDH remained within the exponential range, reaction conditions were optimized by assessing the variation in signal intensity for the two genes at various cycle numbers. Three different primer ratios were tested to achieve the same efficiency of amplification, and the ratio 1:1 was used (data not shown). The primers of rat GAPDH were added after the first 15 cycles of the reaction. Ten of the fifty microliters of amplification products were run on a $1.5 \%$ TrisBorate-EDTA agarose gel containing ethidium bromide. The bands of the positive film were scanned, and the density and the width of each PCR product were measured using the NIH Image Program (Wayne 
Rasband, NIH, Bethesda, MD, USA). All primers were from Life Technologies S.r.l.

\section{Protein extraction and Western blot analysis}

Total proteins were extracted from thyroid cell lines as previously described (16). Briefly, confluent cells from three Petri dishes were collected and homogenized in $1 \mathrm{ml}$ buffer containing $250 \mathrm{mM}$ sucrose, $10 \mathrm{mM}$ Hepes-KOH (pH 7.5), $1 \mathrm{mM}$ EDTA, $1 \mathrm{mM}$ phenylmethylsulfonyl fluoride, $10 \mu \mathrm{g} / \mathrm{ml}$ leupeptin and $10 \mu \mathrm{g} / \mathrm{ml}$ aprotinin. The homogenate was centrifuged at $14000 \mathrm{~g}\left(4^{\circ} \mathrm{C}\right.$ for $\left.15 \mathrm{~min}\right)$, and the supernatant (which contained the whole cell lysate) was quantified spectrophotometrically using the Bradford method (17). Thirty micrograms of protein were loaded onto a $4-20 \%$ gradient SDS polyacrylamide gel and subjected to electrophoresis at a constant voltage $(120 \mathrm{~V})$. Electroblotting to a Hybond ECL-polyvinylidene difluoride nitrocellulose membrane (Amersham Pharmacia Biotech) was performed for $2 \mathrm{~h}$ at $125 \mathrm{~mA}$ using a Mini TRANS BLOT electroblotting system (Bio-Rad Laboratories S.r.l.). After $2 \mathrm{~h}$ of blocking at room temperature with TTBS/milk (Tris-buffered saline, 1\% Tween 20, and 5\% non-fat dry milk), the membrane was incubated overnight at $4{ }^{\circ} \mathrm{C}$ in TTBS/milk with a $1 / 1000$ dilution of affinity-purified rabbit anti-NIS $(18,19)$ polyclonal antibody or a $1 / 5000$ dilution of mouse monoclonal anti-human $\beta$-actin antibody (Sigma-Aldrich S.r.l.). After one 5-min and two 5-min washes in TTBS, the membrane was incubated with a $1 / 2000$ dilution of horseradish peroxidase-conjugated anti-rabbit or anti-mouse antibody (Amersham Pharmacia Biotech) in TTBS/milk. After one 15-min and two 5-min washes in TTBS, the protein was visualized with an enhanced chemiluminescence Western blot detection system (ECL-Plus; Amersham Pharmacia Biotech) and quantified by means of densitometric scanning.

\section{Statistical analysis}

Results are expressed as means \pm S.E.M. Differences between individual points of stimulation were evaluated by analysis of variance (one-factor ANOVA) followed by $t$-test. A level of $P<0.05$ was considered statistically significant.

\section{Results}

\section{Effects of hCG and TSH on iodide uptake}

We first compared the effects of hCG and TSH on iodide uptake in FRTL-5 cells. In time-course experiments, iodide uptake in FRTL-5 cells that had been precultured for 7 days in the absence of TSH was enhanced by exposure to $1000 \mathrm{IU} / \mathrm{ml}$ hCG. The increased uptake was observed following a latency period of $8 \mathrm{~h}$ and peaked after $72 \mathrm{~h}$ of stimulation (Fig. 1A). Similar results were observed using $1 \mathrm{mU} / \mathrm{ml} \mathrm{TSH}$, although the increase occurred earlier (after a 2-h latency period); as with hCG, the maximum effect was evident after $72 \mathrm{~h}$ of stimulation (Fig. 1B).

To determine whether the actions of the two hormones had been mediated by de novo protein synthesis, the FRTL- 5 cells were grown in the presence or absence of $10 \mu \mathrm{g} / \mathrm{ml}$ cycloheximide, an inhibitor of protein synthesis. Cycloheximide completely abolished the hCG-induced stimulation of iodide uptake and, with the exception of early effects, also that produced by TSH (Fig. 1).

The effect of hCG was concentration dependent with detectable stimulation after the addition of $50 \mathrm{IU} / \mathrm{ml}$

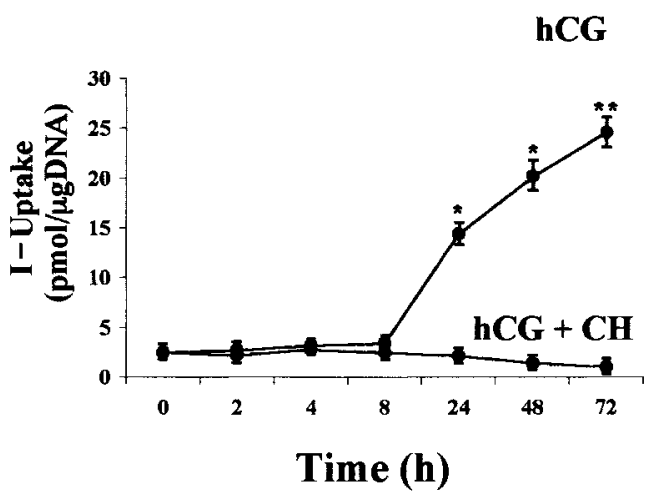

A

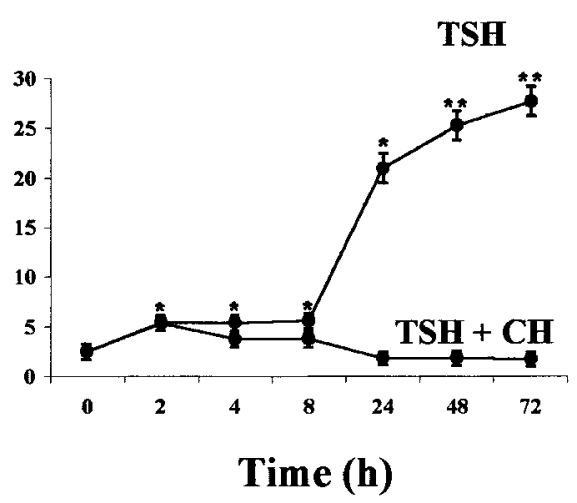

B

Figure 1 Effect of hCG (A) and TSH (B) on iodide uptake in FRTL-5 cells. lodide uptake was measured as described in Materials and methods at the indicated hours after addition of $1000 \mathrm{IU} / \mathrm{ml} \mathrm{hCG} \mathrm{(A)} \mathrm{and} 1 \mathrm{mlU} / \mathrm{ml} \mathrm{TSH}(B)$ at time zero. lodide uptake is expressed as the mean \pm S.E.M. of values obtained from three different experiments. Cycloheximide $(\mathrm{CH})$ completely abolished the hCG-induced stimulation of iodide uptake and, with the exception of early effects $(2 \mathrm{~h})$, also that produced by TSH (see Materials and methods). ${ }^{\star} P=0.001,{ }^{* *} P<0.001$ (ANOVA followed by $t$-test). 


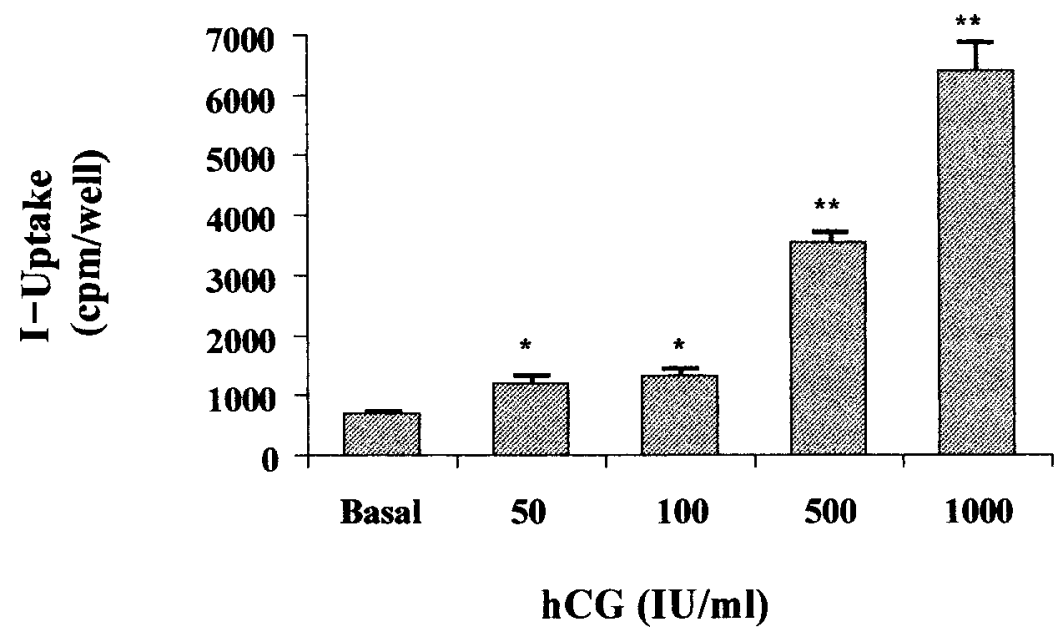

Figure 2 Effect of different doses of hCG on iodide uptake in FRTL-5 cells. lodide uptake was measured as described in Materials and methods after cells had been exposed for $24 \mathrm{~h}$ to various doses of $\mathrm{hCG}$. Data are expressed as the mean \pm S.E.M. of values obtained from two different experiments. ${ }^{\star} P<0.05,{ }^{\star *} P<0.001$ (ANOVA followed by $t$-test).
hCG and maximal enhancement after exposure to $1000 \mathrm{IU} / \mathrm{ml}$ (Fig. 2). This effect was mimicked by $10 \mu \mathrm{M}$ forskolin and by $1 \mathrm{mM}(\mathrm{Bu})_{2}$ cAMP (data not shown). Finally, both the initial and steady-state phases of hCG-stimulated ${ }^{125} \mathrm{I}$ uptake were inhibited by the anion $\mathrm{KClO}_{4}$ (Table 1) and by ouabain, which inhibits $\mathrm{Na}^{+}-\mathrm{K}^{+}-$ATPase (data not shown).

\section{Effects of hCG on NIS mRNA and protein levels}

The effect of hCG on NIS gene expression was then analyzed by using a multiplex semiquantitative RT-PCR. As shown in Fig. 3, time-course studies demonstrated an increase in NIS mRNA levels that was detectable after $4 \mathrm{~h}$ of hCG stimulation; peak levels (a 3.5-fold increase over basal values) were observed after $48 \mathrm{~h}$ (Fig. 3A). Again, a similar pattern of stimulation was observed in FRTL-5 cells stimulated with TSH: in this case, however, increased uptake was evident $2 \mathrm{~h}$ earlier, and the maximal effect was somewhat greater than that seen with hCG (Fig. 3B).

Western blot analysis of NIS protein showed that hCG increased the NIS protein level after $8 \mathrm{~h}$ of stimulation, with a 2.5-fold increase over the basal value

Table 1 Effect of $\mathrm{KClO}_{4}$ on iodide uptake induced by stimulation with hCG. The results are expressed as means \pm S.E.M. of three different experiments.

\begin{tabular}{lcr}
\hline & \multicolumn{2}{c}{ lodide uptake $(\mathrm{pmol} / \mu \mathrm{g}$ DNA $)$} \\
\cline { 2 - 3 } Additions & at $5 \mathrm{~min}$ & at $40 \mathrm{~min}$ \\
\hline None & $20.64 \pm 0.88$ & $29.53 \pm 1.12$ \\
$\mathrm{KClO}_{4}(100 \mu \mathrm{M})$ & $1.02 \pm 0.08$ & $0.78 \pm 0.08$
\end{tabular}

FRTL-5 cells used in iodide-uptake experiments had been grown in TSHfree medium for 7 days and then exposed to $1000 \mathrm{IU} / \mathrm{ml} \mathrm{hCG}$ for $72 \mathrm{~h}$. $\mathrm{KClO}_{4}$ was added in HBSS at the initiation of $\mathrm{I}^{-}$uptake determination, as described in Materials and methods. after $24 \mathrm{~h}$ (Fig. 4A). Similar effects were seen in cells stimulated with cAMP analogs (data not shown) or with TSH, which produced higher peak uptake after $72 \mathrm{~h}$ of stimulation (Fig. 4B).

\section{Discussion}

It is well recognized that hCG possesses a thyroid-stimulating activity that influences thyroid function in normal pregnancy. At 10-12 weeks of gestation, when hCG peaks, there is a decrease in serum TSH levels. In pathological conditions, excessive hCG secretion may cause hyperthyroidism in patients (2). A high proportion of patients with hyperemesis gravidarum present evidence of increased thyroid function although few of them have clinical hyperthyroidism. Many patients with trophoblastic tumors, including benign hydatidiform moles and malignant choriocarcinomas, also show signs of hyperthyroidism, which is cured when the neoplasm is removed or subjected to effective chemotherapy. The mechanism underlying the thyrotropic effects of hCG is believed to be related to the close structural relationships between hCG and TSH and between their receptors. Moreover, a particular mutant TSH receptor has been described that is hypersensitive to hCG at normal concentrations (20).

A number of in vitro experiments also suggest that hCG's effects on the thyroid are the result of its direct interaction with the TSH receptor $(3,4)$. In FRTL-5 rat thyroid cells, hCG has been demonstrated to increase cAMP, iodide transport, and cell growth (5, 21,22 ) and, in cells transfected with the human TSH receptor, it increases cAMP production (4). The results of the present study confirm previous observations that hCG stimulates iodide uptake by thyrocytes. They also demonstrate that this effect parallels that of TSH but without the early, protein synthesis-independent stimulation observed with TSH. The action of hCG can, in 


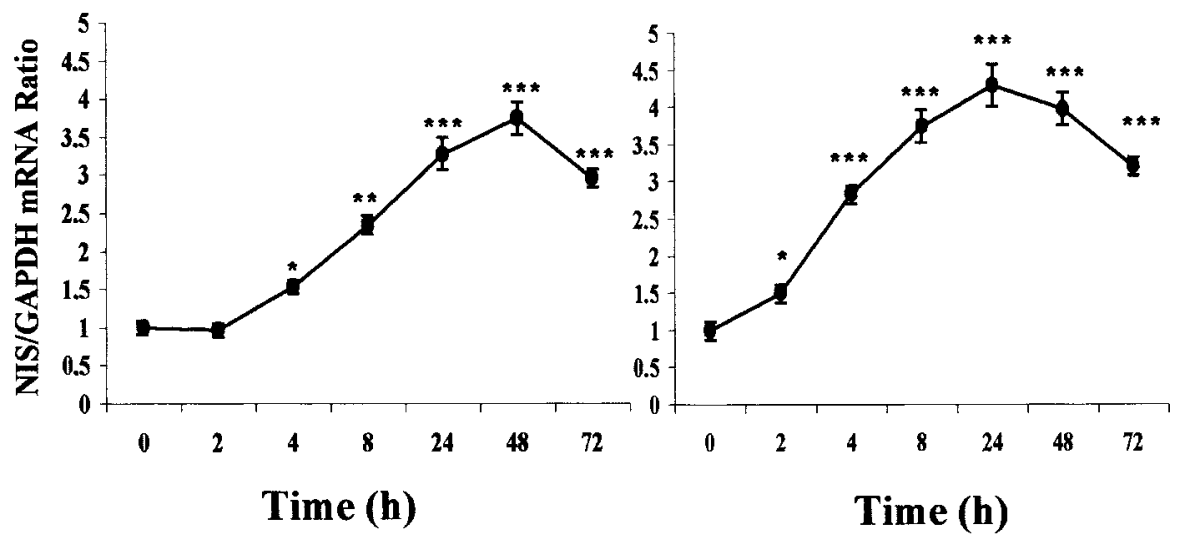

$\mathbf{A}$

B

Figure 3 Effects of hCG (A) and TSH (B) on NIS mRNA levels in FRTL- 5 cells. FRTL- 5 cells were grown in 100 mm diameter dishes in medium without hCG or TSH (see Materials and methods) and then exposed to $1000 \mathrm{lU} / \mathrm{ml} \mathrm{hCG} \mathrm{(A)} \mathrm{or} 1 \mathrm{mlU} / \mathrm{ml} \mathrm{TSH}$ (B) for the indicated periods of time. Total RNA was extracted from duplicate dishes of cells (as described in Materials and methods), and the levels of RNA were measured using a semiquantitative multiplex RT-PCR. Data are expressed as the mean \pm S.E.M. of values obtained from at least three different experiments. ${ }^{\star} P<0.05,{ }^{* \star} P=0.002,{ }^{* \star *} P<0.001$ (ANOVA followed by $t$-test).

fact, be fully attributed to the increases it provokes in levels of NIS mRNA and the NIS protein itself. The increased iodide uptake induced by hCG was observed after a lag period of $8 \mathrm{~h}$, which is compatible with the time requirements for a significant effect on NIS protein biosynthesis, and it was fully abolished by addition to the growth medium of the protein synthesis inhibitor, cycloheximide.

The central role of the NIS in mediating the thyrotropic effects of hCG is also supported by other observations. For example, the serum of pregnant women has been shown to exert thyroid-stimulating activity in vitro (23), and iodide uptake is correlated with serum hCG levels during the first, but not the third, trimester of pregnancy (24). The NIS protein is also expressed in human placenta (25), and we have recently found that expression of the NIS gene in placental samples from the first trimester is, in fact, higher than that of third trimester samples (26). NIS gene expression parallels that of the hCG- $\beta$ gene, and it is stimulated in vitro by a cAMP analog (26). Thus, by acting on the expression of NIS in both thyroid and trophoblast cells, hCG modulates the uptake and transplacental passage of iodide, influencing both maternal

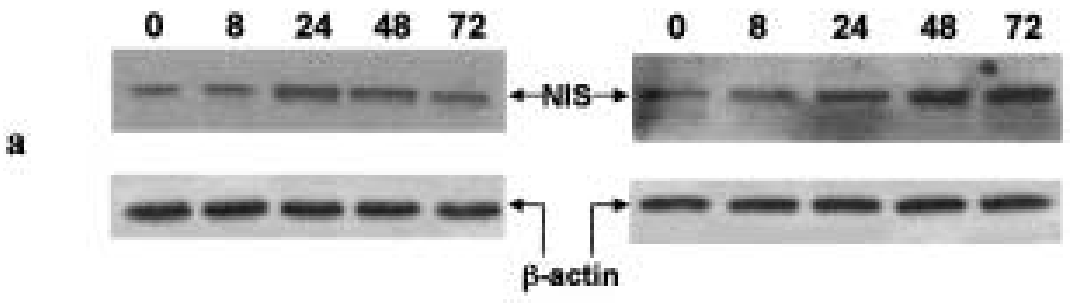

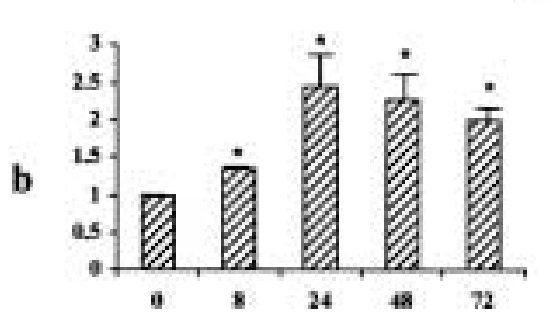

Time (h)

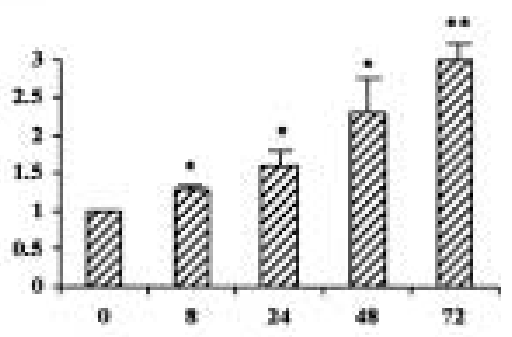

Time (h)
Figure 4 Effect of hCG (A) and TSH (B) on NIS protein expression in FRTL-5 cells. Whole-cell protein extracts from FRTL- 5 cells stimulated with $1000 \mathrm{IU} / \mathrm{ml}$ hCG (A) or $1 \mathrm{mIU} / \mathrm{ml} \mathrm{TSH}(B)$ for the indicated periods of time were examined by Western blot analysis using a polyclonal anti-NIS antibody and a monoclonal anti-human $\beta$-actin antibody as described in Materials and methods. (a) Autoradiograph of a representative experiment.

(b) Staining intensity is expressed as the mean \pm S.E.M. of values obtained from two different experiments. Data are expressed relative to the control values (time 0 ). ${ }^{\star} P<0.05,{ }^{\star *} P<0.001$ (ANOVA followed by $t$-test). 
and fetal thyroid function in an early critical stage of pregnancy.

It has recently been reported that TSH stimulation of iodide uptake by FRTL- 5 cells is mediated not only by increases in the transcription and biosynthesis of the NIS, but also by its targeting to and/or retention in the plasma membrane which is thought to be dependent upon protein phosphorylation (27). This might account for the dissociation observed in early studies between the magnitude of increase in iodide uptake and the amount of NIS protein found after TSH stimulation $(28,29)$, and it could also explain our observation of the incomplete abolition of TSH's effects by the protein synthesis inhibitor cycloheximide. It thus appears that, at least in FRTL-5 cells, very low levels of NIS protein may be produced in the absence of TSH, although the presence of the hormone is probably required for the complete execution of NIS-mediated activities. In contrast, hCG's effects develop much more gradually ( $8 \mathrm{~h}$ vs $2 \mathrm{~h}$ latency with TSH) and are completely abolished by cycloheximide. These findings indicate that, at least in vitro, TSH regulation of the delicate function of iodide uptake is a complex phenomenon, with early and late effects and both transcriptional and non-transcriptional mechanisms, whereas hCG is responsible only for longer-term effects that depend exclusively on the de novo synthesis of the NIS protein. These latter effects are likely to play an important role during pregnancy. Considering that many other factors, including iodide (30), estradiol $(31,32)$ and certain cytokines $(11,12)$, can also modify iodide uptake by acting on NIS expression, and that these factors are themselves subject to pregnancy related modifications, we feel that elucidation of the mechanisms that regulate NIS expression may help to clarify the pathogenesis of a number of thyroid disorders that are associated with pregnancy.

\section{Acknowledgements}

This work was supported by a grant to S F (MURSTCofin 2000) and D R (MURST-Cofin 2000). We wish to thank Ms Marian Kent for editorial assistance.

\section{References}

1 Hershman JM. Editorial: role of human chorionic gonadotropin as a thyroid stimulator. Journal of Clinical Endocrinology and Metabolism $199274258-259$.

2 Glinoer D. The regulation of thyroid function in pregnancy: pathways of endocrine adaptation from physiology to pathology. Endocrine Reviews $1997 \mathbf{1 8} 404-433$.

3 Tomer Y, Huber GK \& Davies TF. Human chorionic gonadotropin (hCG) interacts directly with recombinant human TSH receptors. Journal of Clinical Endocrinology and Metabolism $1992 \quad \mathbf{7 4}$ 1477-1479.

4 Yoshimura M, Hershman JM, Pang X-P, Berg L \& Pekary AE. Activation of the thyrotropin (TSH) receptor by human chorionic gonadotropin and luteinizing hormone in Chinese hamster ovary cells expressing functional human TSH receptors. Journal of Clinical Endocrinology and Metabolism 199377 1009-1013.

5 Hershman JM, Lee HY, Sugawara M, Mirell CJ, Pang XP, Yanagisawa $\mathrm{M}$ et al. Human chorionic gonadotropin stimulates iodide uptake, adenylate cyclase, and deoxyribonucleic acid synthesis in cultured rat thyroid cells. Journal of Clinical Endocrinology and Metabolism 198867 74-79.

6 Yoshikawa N, Nishikawa M, Horimoto M, Yoshimura M, Toyoda N \& Inada M. Human chorionic gonadotropin promotes thyroid growth via thyrotropin receptors in FRTL-5 cells. Endocrinologia Japonica 199037 639-648.

7 Yoshimura M, Nishikawa M, Mori Y, Yoshikawa N, Horimoto M, Toyoda $\mathrm{N}$ et al. Human chorionic gonadotropin induces c-myc mRNA expression via TSH receptor in FRTL-5 rat thyroid cells. Thyroid 19922 315-319.

8 Kraiem Z, Sadeh O, Blithe DL \& Nisula BC. Human chorionic gonadotropin stimulates thyroid hormone secretion, iodide uptake, organification, and adenosine $3^{\prime}, 5^{\prime}$ - monophosphate formation in cultured human thyrocytes. Journal of Clinical Endocrinology and Metabolism 199479 595-599.

9 Dai G, Levy O \& Carrasco N. Cloning and characterization of the thyroid iodide transporter. Nature $1996379458-460$.

10 Filetti S, Bidart JM, Arturi F, Caillou B, Russo D \& Schlumberger M. Sodium/iodide symporter (NIS): a key transport system in thyroid cancer cell metabolism. European Journal of Endocrinology 1999 $141443-457$.

11 Spitzweg C, Heufelder AE \& Morris JC. Thyroid iodide transport. Thyroid $200010321-330$.

12 Dohan O, De La Vieia A \& Carrasco N. Molecular study of the sodium/iodide symporter (NIS): a new field in thyroidology. Trends in Endocrinology and Metabolism 2000 11 99-105.

13 Ambesi-Impiombato FS, Parks LAM \& Coon HG. Culture of hormone-dependent functional epithelial cells from rat thyroids. PNAS 198077 3455-3459.

14 Weiss SJ, Philp NJ \& Grollman EF. Iodide transport in a continuous line of cultured cells from rat thyroid. Endocrinology $1984 \mathbf{1 1 4}$ 1090-1098.

15 Arturi F, Russo D, Giuffrida D, Ippolito A, Perrotti N, Vigneri R et al. Early diagnosis by genetic analysis of differentiated thyroid cancer metastases in small lymph nodes. Journal of Clinical Endocrinology and Metabolism 199782 1638-1641.

16 Arturi F, Russo D, Bidart JM, Scarpelli D, Schlumberger M \& Filetti $\mathrm{S}$. Expression pattern of the pendrin and sodium-iodide symporter gene in human thyroid carcinoma cell lines and human thyroid tumors. European Journal of Endocrinology 2001 145 129-135.

17 Bradford MM. A rapid and sensitive method for the quantitation of microgram quantities of protein utilizing the principle of protein dye binding. Analytical Biochemistry $1976 \mathbf{7 2} 248-254$.

18 Russo D, Bulotta S, Bruno R, Arturi F, Giannasio P, Derwahl M et al. Sodium/iodide symporter (NIS) and pendrin are expressed differently in hot and cold nodules of thyroid toxic multinodular goiter. European Journal of Endocrinology 2001145 591-596.

19 Caillou B, Troalen F, Baudin E, Talbot M, Filetti S, Schlumberger $\mathrm{M}$ et al. $\mathrm{Na}^{+} / \mathrm{I}^{-}$symporter distribution in human thyroid tissues: an immunohistochemical study. Journal of Clinical Endocrinology and Metabolism $1998 \mathbf{8 3} 4102-4106$.

20 Rodien P, Bremont C, Sanson ML, Parma J, Van Sande J, Costagliola S et al. Familial gestational hyperthyroidism caused by a mutant thyrotropin receptor hypersensitive to human chorionic gonadotropin. New England Journal of Medicine 1998 $3391823-1826$.

21 Davies TF \& Platzer M. hCG-induced receptor activation and growth acceleration in FRTL-5 thyroid cells. Endocrinology 1986 $1182149-2151$.

22 Ballabio M, Sinha AK \& Ekins RP. Thyrotropic activity of crude hCG in FRTL-5 rat thyroid cells. Acta Endocrinologica 1987116 479-488.

23 Yoshimura M, Nishikawa M, Horimoto M, Yoshikawa N, Sawaragi S, Horokoshi Y et al. Thyroid-stimulating activity of 
human chorionic gonadotropin in sera of pregnant women. Acta Endocrinologica $1990123277-281$.

24 Kennedy RL, Darne J, Cohn M, Price A, Davies R, Blumsohn A et al. Human chorionic gonadotropin may not be responsible for thyroid-stimulating activity in normal pregnancy serum. Journal of Clinical Endocrinology and Metabolism $1992 \quad \mathbf{7 4}$ 260-265.

25 Mitchell AM, Manley SW, Morris JC, Powell KA, Berget ER \& Mortimer RH. Sodium iodide symporter (NIS) gene expression in human placenta. Placenta 200122 256-258.

26 Bidart JM, Lacroix L, Evain-Brion D, Caillou B, Lazar V, Frydman $\mathrm{R}$ et al. Expression of $\mathrm{Na}^{+} / \mathrm{I}^{-}$symporter and Pendred syndrome genes in trophoblast cells. Journal of Clinical Endocrinology and Metabolism $2000 \mathbf{8 5} 4367-4372$.

27 Riedel C, Levy O \& Carrasco N. Post-transcriptional regulation of the sodium/iodide symporter by thyrotropin. Journal of Biological Chemistry $200127621459-21463$.

28 Kaminski SM, Levy O, Salvador C, Dai G \& Carrasco N. $\mathrm{Na}^{+} / \mathrm{I}^{-}$ symporter activity is present in membrane vesicles from thyrotropin-deprived non- $\mathrm{I}^{-}$transporting cultured thyroid cells. PNAS 199491 3789-3793.
29 Kogai T, Endo T, Saito T, Miyazaki A, Kawaguchi A \& Onaya T. Regulation by thyroid-stimulating hormone of sodium/iodide symporter gene expression and protein levels in FRTL-5 cells. Endocrinology $19971382227-2232$.

30 Eng PH, Cardona GR, Previti MC, Chin WW \& Braverman LE. Regulation of the sodium/iodide symporter by iodide in FRTL-5 cells. European Journal of Endocrinology 2001 144 139-144.

31 Furlanetto TW, Nguyen LQ \& Jameson JL. Estradiol increases proliferation and down-regulates the sodium/iodide symporter gene in FRTL-5 cells. Endocrinology 1999140 5705-5711.

32 Spitzweg C, Joba W, Morris JC \& Heufelder AE. Regulation of sodium iodide symporter gene expression in FRTL-5 rat thyroid cells. Thyroid $19999821-830$.

Received 28 March 2002

Accepted 16 July 2002 